\title{
Nutrient additions resulting in phage release and formation of non-nucleoid-containing bacteria
}

\author{
David Lymer ${ }^{1, *}$, Katarina Vrede $^{1,2}$ \\ ${ }^{1}$ Limnology/Department of Ecology and Evolution, Evolutionary Biology Centre, Uppsala University, Norbyv. 20, \\ 75236 Uppsala, Sweden
}

${ }^{2}$ Present address: The Swedish Research Council for Environment, Agricultural Sciences and Spatial Planning (FORMAS), Box 1206, 11182 Stockholm, Sweden

\begin{abstract}
The responses of aquatic bacteriophages to (1) P additions in P-limited batch cultures and (2) separate $\mathrm{P}$ and $\mathrm{N}$ additions in batch cultures that were both $\mathrm{P}$ - and $\mathrm{N}$-limited were monitored. Possible connections between the abundance of non-nucleoid-containing cells (non-Nu CC) and viral abundance were also examined. The water used in the experiments was collected from the mesotrophic Lake Erken (Sweden) in late autumn. In both experiments, nutrient addition resulted in increases in viral abundance and non-nucleoid-containing bacterial cells. However, in the P- and Nlimited cultures, P addition resulted in increases in viral abundance and non-nucleoid-containing bacterial cells, but no increase in bacterial abundance. In contrast, in the cultures to which $\mathrm{N}$ was added, increases in viral abundance were accompanied by increases in the abundance of both bacteria and non-nucleoid-containing cells. The results show that there is a connection between changes in the abundance of viruses and non-nucleoid-containing cells. However, there are indications that viral abundance can change in response to changes in the P status of the environment without any increase in bacterial abundance.
\end{abstract}

KEY WORDS: NuCC $\cdot$ Phosphorus-limitation $\cdot$ Phage $\cdot$ Virus

Resale or republication not permitted without written consent of the publisher

\section{INTRODUCTION}

Bacteria comprise a large proportion of the planktonic biomass in aquatic systems, especially in oligotrophic and humic lakes (Hessen et al. 1990, Blomqvist et al. 1995). However, a large fraction of the bacterial community has been found to be inactive or dormant, and the active fraction varies between different aquatic habitats (Haglund et al. 2002). A large fraction of the bacteria in aquatic environments may contain no visible nucleoid. It has been suggested that these non-nucleoid-containing cells (non-NuCC) might be products of viral lysis or remains of flagellate grazing (Zweifel \& Hagström 1995). However, it has been shown that some of the non-NuCC could be transformed, under appropriate culture conditions, into NuCC (Choi et al. 1996). Reported values of the abundance of NuCC, as a percentage of the total bacterial population, vary from $<30$ to $>50 \%$ in marine environments (reviewed by Gasol et al. 1999), from 13 to $52 \%$ in freshwater sediments (Haglund et al. 2003), and from 1.4 to $42.9 \%$ in freshwater (Berman et al. 2001).

During the last 2 decades it has been recognised that viruses are abundant in seawater (Bergh et al. 1989) and frequently infect bacterioplankton (Proctor \& Fuhrman 1990). Viruses are typically more abundant in freshwater than in marine environments (Maranger \& Bird 1995). The release of organic carbon (C) and nutrients following lysis can be regarded as a recycling process, whereby new viruses and cellular products of the host organisms are returned to dissolved/suspended organic matter phases of the $\mathrm{C}$ and nutrient cycles (Fisher \& Velimirov 2002). The products of cell lyses can then be utilised by other bacteria (Middelboe et al. 1996, 2003, Noble \& Fuhrman 1999, Middelboe et al. 2003). Viral infections may enhance bacteria- 
specific production rates, but their net effect will be a loss of $\mathrm{C}$, since most of the organic $\mathrm{C}$ pool is used for respiration by the bacteria (Middelboe \& Lyck 2002). Utilisation of the nutrient-rich lysates may be an important feature of nutrient recycling in oligotrophic waters (Noble \& Fuhrman 1999), where nutrient availability limits bacterial production. It has also been found that bacteria assimilate more inorganic phosphorus (P) than virally released P. This is probably because virally released $\mathrm{P}$ occurs mainly in organic forms, which the bacteria must enzymatically cleave before use (Gobler et al. 1997). Hence, utilisation of organic $\mathrm{P}$ is likely to be most important in oligotrophic systems where $\mathrm{P}$ is in scarce supply. This is in contrast to iron (Fe) from lysates, which is more readily bioavailable than inorganic Fe sources, and hence more rapidly assimilated (Poorvin et al. 2004).

Addition of $\mathrm{P}$ to water samples can cause a drop in bacterial abundance, possibly because increased nutrient availability can induce lysogenic viruses to become lytic (Tuomi et al. 1995). Other authors have observed increases in bacterial production rates following $\mathrm{P}$ additions, but no accompanying increases in bacterial abundance, and have speculated that virusinduced mortality could be responsible for this apparent anomaly (DeBruyn et al. 2004). It has also been suggested that since viral particles contain a relatively high amount of $\mathrm{P}$ compared to nitrogen $(\mathrm{N})$, viruses may be more sensitive to $\mathrm{P}$-limitation than $\mathrm{N}$-limitation (Bratbak et al. 1993).

In the present study, we investigated the link between bacteria without visible nucleoids (non$\mathrm{NuCC}$ ) and bacteriophages, and the effects of nutrient availability on the production of viruses and nonNuCC. We hypothesised that viruses are responsible, in part, for the production of non-NuCC. Further, we hypothesised that virus production can be stimulated by additions of nutrients, especially P. We conducted 2 experiments to test these hypotheses, whereby natural bacterial and viral communities were manipulated with nutrient additions.

\section{MATERIALS AND METHODS}

Experimental design. Water was collected from the mesotrophic Lake Erken (Sweden) with a Ruttner sampler on 15 October (0 to $5 \mathrm{~m}$; P-limited experiment, P expt) and 23 November 1999 (1 to 5 m; N/P-limited experiment, N/P expt). Bacterial abundance (BA) varies between 0.7 and $2.1 \times 10^{9}$ cells $^{-1}$ (Vrede et al. 1999) and viral abundance between 0.8 and $3.5 \times$ $10^{11} \mathrm{l}^{-1}$ in this lake (D. Lymer unpubl. data). The water was mixed to homogenise the sample and filtered through a glass microfibre filter (Whatman GF/C), and then through a $1.0 \mu \mathrm{m}$ polycarbonate filter (Micron Separations) to remove all organisms except bacteria and viruses. In a study of 5 lakes (Lindström 2000), no effect of $1.0 \mu \mathrm{m}$ filtration was found on BA, except in the most eutrophic lake, in which a high proportion of bacteria were relatively large, 23 to $47 \%$ of them being retained on the $1.0 \mu \mathrm{m}$ filters. In mesotrophic Lake Erken, the bacteria are smaller, especially in late autumn, and hence $1.0 \mu \mathrm{m}$ filtration probably had a very minor effect on the BA. The $1.0 \mu \mathrm{m}$-filtered lakewater samples were passed through $0.2 \mu \mathrm{m}$ membrane filters (Schleicher \& Schuell) to remove the bacteria, and experiments were started with 1:1 mixtures of the $1.0 \mu \mathrm{m}$-filtered and $0.2 \mu \mathrm{m}$-filtered lakewater. The bottles were aerated and mixed by gentle bubbling with $0.02 \mu \mathrm{m}$-filtered air and incubated in darkness at $10^{\circ} \mathrm{C}$. The major difference in the 2 experiments was that the bacterial community was P-limited $(0.03$ to $0.04 \mu \mathrm{M}$ $\mathrm{PO}_{4} \mathrm{l}^{-1}$ and $4.3 \mu \mathrm{M} \mathrm{NH}_{4} \mathrm{l}^{-1}$ ) in the first experiment (P expt), and co-limited by $\mathrm{P}$ and $\mathrm{N}\left(0.11 \mu \mathrm{M} \mathrm{NH}_{4} \mathrm{l}^{-1}\right.$ and $<0.03 \mu \mathrm{M} \mathrm{PO}_{4} \mathrm{l}^{-1}$ ) in the second (N/P expt) before nutrient addition (which followed a pre-incubation phase, as described in later subsection). The $\mathrm{NH}_{4} \mathrm{Cl}$, $\mathrm{NaH}_{2} \mathrm{PO}_{4}$ and $\mathrm{C}_{6} \mathrm{H}_{12} \mathrm{O}_{6}$ (glucose) nutrient solutions used in the experiments were autoclaved for $1 \mathrm{~h}$ at $122^{\circ} \mathrm{C}$ before use.

$P$-limited experiment ( $P$ expt): In this experiment, lakewater filtrate was batch-cultured in six 51 bottles, with 21 of filtrate in each bottle. All bottles were enriched with $\mathrm{C}$ and $\mathrm{N}$ (to $28.6 \mu \mathrm{M} \mathrm{NH} \mathrm{NH}_{4}-\mathrm{N} \mathrm{l}^{-1}$ and $0.2 \mathrm{mM} \mathrm{C} \mathrm{l}^{-1}$ ) to reduce the $\mathrm{PO}_{4}$ concentration. The bottles were then pre-incubated for $45 h_{i} 3$ bottles received no further nutrients (controls), while $\mathrm{NaH}_{2} \mathrm{PO}_{4}$ was added to the other 3 bottles, to a $\mathrm{PO}_{4}-\mathrm{P}$ concentration of $1.29 \mathrm{\mu M} \mathrm{l}^{-1}$, raising the total $\mathrm{P}$ concentration (tot-P) from 0.42 to $0.74 \mu \mathrm{M} \mathrm{P} \mathrm{l}^{-1}$ (a statistically significant increase, according to Fisher's least-significant difference [LSD] test; $\mathrm{p}=0.00017, \mathrm{n}=3$ ). Water from 2 bottles in each treatment was sampled at the start of the pre-incubation phase, and after $5,45 \mathrm{~h}$ (just before nutrient additions), 55 and $75 \mathrm{~h}$, to determine the abundance of viruses (VA), bacteria (BA), nucleoid-containing cells $(\mathrm{NuCC})$ and non-nucleoidcontaining cells (non-NuCC). In addition, all 3 bottles in each treatment were sampled at each of these time points to determine $\mathrm{PO}_{4}$, tot- $\mathrm{P}, \mathrm{NH}_{4}$ and heterotrophic nanoflagellate abundance (HNFA).

N/P-limited experiment (N/P expt): We pre-incubated $10 \mathrm{l}$ of water for $6 \mathrm{~d}$, during which time glucose was added 3 times $(1.67 \mathrm{mM} \mathrm{C}$ per addition, giving an excess of organic $\mathrm{C}$ ). On the 5th day, $\mathrm{NH}_{4} \mathrm{Cl}$ was added (to $1.78 \mu \mathrm{M} \mathrm{N} \mathrm{l}^{-1}$ ) to ensure that all available $\mathrm{PO}_{4}$ in the water was taken up. After the $6 \mathrm{~d}$ pre-incubation period, $1000 \mathrm{ml}$ of the water was poured into each of nine $1 \mathrm{l}$ bottles, 3 of which were allocated to each of 
3 different treatments: control (no nutrients added), $\mathrm{NH}_{4} \mathrm{Cl}$ addition (to $12.9 \mu \mathrm{M} \mathrm{NH} \mathrm{NH}^{-1}$ ) and $\mathrm{NaH}_{2} \mathrm{PO}_{4}$ addition (to $1.29 \mu \mathrm{M} \quad \mathrm{PO}_{4}-\mathrm{P} \quad \mathrm{l}^{-1}$ ). The nutrients were added $1 \mathrm{~h}$ (Time 1) after transfer of the water to the bottles.

Viral, bacterial and flagellate abundance. Viruses, bacteria and flagellates were counted under a Nikon epifluorescence microscope $(1250 \times)$ in formaldehyde ( $4 \%$ )-preserved samples that had been stored at $4{ }^{\circ} \mathrm{C}$. Viruses were stained with SYBR Green I (Noble \& Fuhrman 1998) and observed using a Nikon Plan 100/1.25 lens and a Nikon B-2A filter. Bacteria were stained with DAPI (Zweifel \& Hagström 1995, Choi et al. 1996) and observed using a Zeiss Neofluar 100/1.30 lens and a UV-1A filter. To discriminate between $\mathrm{NuCC}$ and non-NuCC, non specifically bound dye was removed by adding $0.25 \mathrm{ml}$ of 2-propanol to DAPIstained samples (Zweifel \& Hagström 1995, Choi et al. 1996). The bacteria were then counted as described above. Flagellates were stained with acridine orange and observed using a Nikon 40/0.70 lens. No flagellates were found in any of the treatments in either of the 2 experiments.

Water chemistry. Concentrations of $\mathrm{PO}_{4}-\mathrm{P}$ (Murphy \& Riley 1962), $\mathrm{NH}_{4}-\mathrm{N}$ (Chaney \& Marbach 1962) and tot-p (Menzel \& Corwin 1965) were measured immediately after each sampling.

Statistics. Statistica 6.0 was used for all statistical analyses. The effects of pre-incubation on VA, BA, $\mathrm{NuCC}$ and non-NuCC were tested with 1-way ANOVA in the P expt. The effects of P-addition in the $P$ expt and the effects of the treatments in the N/P expt were tested with repeated-measurement ANOVAs using Fisher's LSD post hoc test.

\section{RESULTS}

\section{P experiment}

Pre-incubation resulted in no significant change in BA $(p>0.05)$ or NuCC $(p>0.05)$, but there were significant decreases in VA $(p<0.0001)$ and non$\mathrm{NuCC}(p=0.0014)$; these decreased to 60 and $37 \%$ of their initial values, respectively. After nutrient addition, the $\mathrm{PO}_{4}$ concentration remained constant in both treatments (varying between 0.03 and $0.06 \mu \mathrm{M} \mathrm{P} \mathrm{l}^{-1}$ ), and there was no significant difference in $\mathrm{PO}_{4}$ concentrations between them (Fisher's LSD p > 0.0.05; $\mathrm{n}=3$ ), suggesting that the added $\mathrm{PO}_{4}$ was rapidly assimilated and converted to bacterial P. The $\mathrm{NH}_{4}$ concentration was depleted after $10 \mathrm{~h}$ in the P-treatment. In the control bottles the decrease was slower, the concentration being $2.9 \mu \mathrm{M} \mathrm{N}^{-1}$ after $20 \mathrm{~h}$ and $1.8 \mu \mathrm{M} \mathrm{N}^{-1}$ after $30 \mathrm{~h}$.
BA and NuCC were higher in the P-treatment than the control after $10 \mathrm{~h}$, and remained higher throughout the remainder of the experiment (Fig. 1). The abundance of non-NuCC more than doubled (increasing 2.9 -fold) in the P-treatment after $10 \mathrm{~h}$, but decreased in the control during the same period. After $10 \mathrm{~h}$ incubation, non-NuCC in the P-treatment decreased and was lower than in the control at $30 \mathrm{~h}$ (Fig. 1). VA initially decreased in the control and then increased to pre-
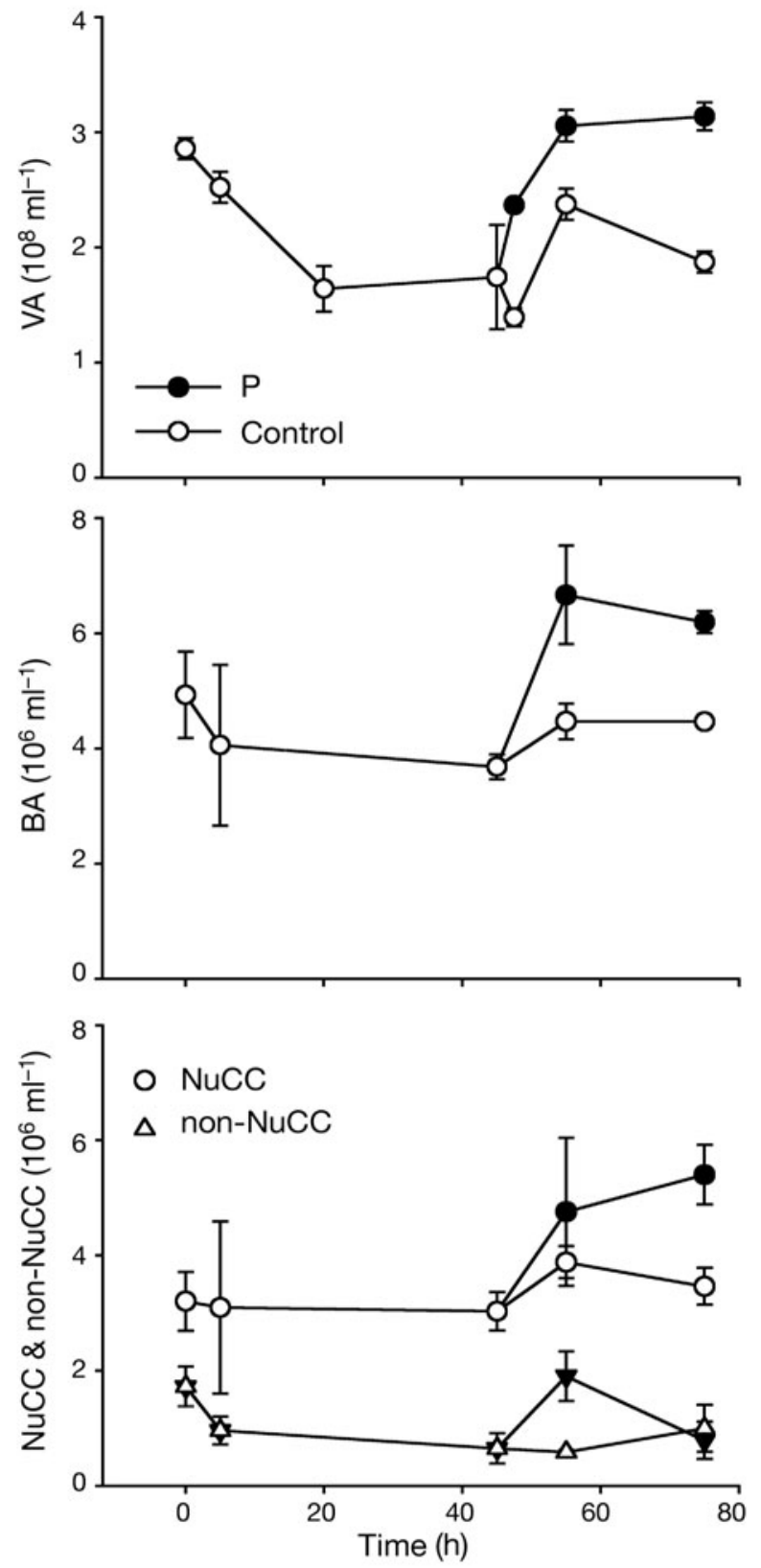

Fig. 1. Mean $( \pm \mathrm{SD})$ changes in abundance of viruses (VA), bacteria (BA), nucleoid-containing bacteria (NuCC) and nonnucleoid containing bacteria (non-NuCC) in response to the $\mathrm{P}$-treatment in the $\mathrm{P}$ expt at Time $1 ; \mathrm{n}=2$ for all parameters. In some cases, error bars are smaller than symbols 
addition levels, remaining at these levels for the rest of the experiment (Fig. 1). In the P-treatment the VA almost doubled (increasing 1.8-fold) during the first $10 \mathrm{~h}$ incubation and remained at this high level throughout the rest of the experiment.

\section{N/P experiment}

The $\mathrm{NH}_{4}$ concentration decreased to $9.28 \mu \mathrm{M} \mathrm{N} \mathrm{l}^{-1}$ in the $\mathrm{N}$-treatment after $10 \mathrm{~h}$, but it was still significantly higher than in the P-treatment, and the control ( $p<0.00001)$. In the control and P-treatments the $\mathrm{NH}_{4}$ concentration remained low throughout the experiment, and there was no significant difference between them in this respect ( $p>0.05)$. In the P-treatment, the $\mathrm{PO}_{4}$ concentration decreased slowly during the experiment to about $2.86 \mu \mathrm{M} \mathrm{P}^{-1}$ after $10 \mathrm{~h}$, and was significantly different from the control and the N-treatment ( $p<0.0001)$. In the control and $\mathrm{N}$-treatments the $\mathrm{PO}_{4}$ concentrations were low $\left(<0.16 \mu \mathrm{M} \mathrm{P}^{-1}\right)$ throughout the experiment, and there was no significant difference between them in this respect ( $p>0.05)$.

$\mathrm{BA}, \mathrm{VA}, \mathrm{NuCC}$ and non-NuCC all differed between treatments $(p<0.05)$. BA increased in the $\mathrm{N}$-treatment and remained significantly higher than in the other treatments throughout the experiment (Fig. 2, p < 0.0001). In the P-treatment and control there were small reductions in BA (Fig. 2) and there was no significant difference in BA between these treatments $(p>0.05)$. NuCC showed a decrease in the P-treatment and was significantly lower than in the control ( $p=0.001)$, remaining relatively constant (Fig. 2). In contrast, NuCC increased in the $\mathrm{N}$-treatment and was significantly higher than in the control (Fig. 2, p=0.004). Hence, the abundance of NuCC in the N-treatment was significantly higher than in the P-treatment $(p<0.0001)$. The abundance of non-NuCC increased more in the P- and $\mathrm{N}$-treatments than in the control (Fig. 2). The treatments differed significantly in this respect $(C, P: p=0.0045$; $\mathrm{C}, \mathrm{N}: \mathrm{p}<0.0001$ ), and initially the abundance of non-NuCC in the N-treatment was significantly higher than in the P-treatment (Fig. 2, p=0.0021). VA increased more in both the $\mathrm{N}$ - and P-treatments than in the control in the first $5 \mathrm{~h}$ (Fig. 2). From 5 to $10 \mathrm{~h}$ there was a decrease in all treatments and the decrease was more pronounced in the N-treatment than in the P-treatment. VA was significantly higher in both the $\mathrm{N}$ - and P-treatments than in the control $(\mathrm{p}<0.0001)$.

\section{DISCUSSION}

In the N/P expt the N-treatment induced increases in both VA and BA, but the P-treatment induced
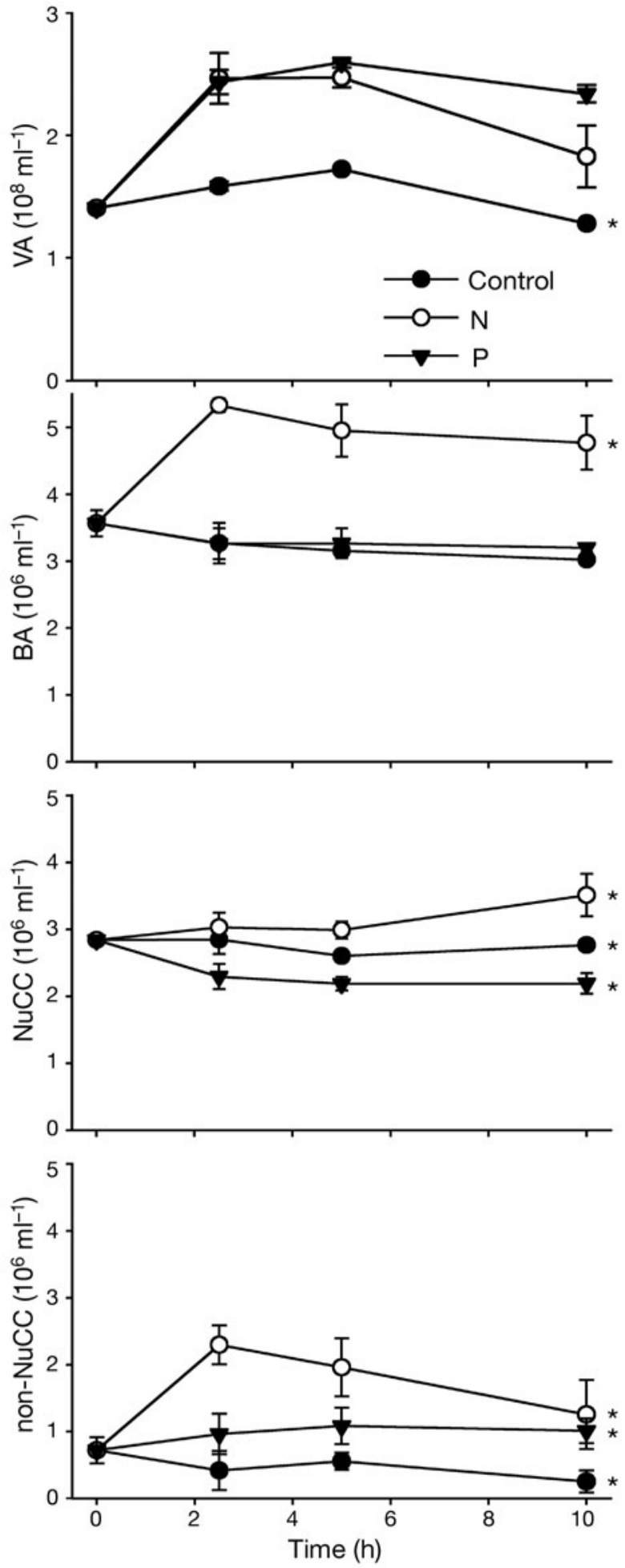

Fig. 2. Mean $( \pm \mathrm{SD})$ changes in the abundance of viruses (VA), bacteria (BA), nucleoid-containing bacteria (NuCC) and nonnucleoid-containing bacteria (non-NuCC) in response to nutrient additions in the N/P expt at Time $1 ; \mathrm{n}=3$ for BA, $\mathrm{NuCC}$ and non-NuCC, $\mathrm{n}=2$ for VA. In some cases, error bars are smaller than symbols. *: Result for relevant treatment was significantly different $(p<0.05)$ from results for the other treatments 
increases in VA that were not accompanied by increases in BA. In fact, there was a significant decrease in the abundance of NuCC compared to the control and the N-treatment. Hence, the results indicate that in this treatment the increase in VA was not supported by bacterial growth (Fig. 2). A previous study indicated that $\mathrm{P}$ is a major influence on virus production, but concluded that virus production occurs through increased host cell activity (Williamson \& Paul 2004). The results of our experiment indicate that virus production can be stimulated by $\mathrm{P}$ addition without an increase in bacterial growth. Here, the stimulation of virus production resulted, instead, in a decrease in NuCC abundance.

In both experiments there was a co-occurrence of increasing VA and increasing abundance of non$\mathrm{NuCC}$. In phage-host systems investigated by Wolf et al. (2004) the frequency of virus-infected cells (FVIC) increased from 1 to $57 \%$ after nutrient addition $(C, N$ and $\mathrm{P}$ ) and then declined to $5 \%$ within $24 \mathrm{~h}$. The rapid responses in VA and non-NuCC observed in the experiments in the present study probably reflect similar phenomena, with high initial production of viral particles and lysis of cells within the first few hours following nutrient addition and then declining infection and lysis. Hence, VA quickly rose at the beginning of the experiments to a level that was maintained throughout the rest of the experiment.

The initial appearance of non-NuCC was followed by a decrease in non-NuCC abundance in the $\mathrm{P}$ expt and for the N-treatment in the N/P expt, probably due to disintegration of the lysed cells. The decrease in the $\mathrm{N}$-treatment in the N/P expt was detected just $2.5 \mathrm{~h}$ after the highest non-NuCC abundance had been measured, i.e. $5 \mathrm{~h}$ into the experiment (Fig. 2). Accordingly, it has been shown that the cell wall in virally infected bacteria can gradually disintegrate and completely disappear within a few hours (Riemann \& Middelboe 2002). Both P- and N-treatments in the N/P expt stimulated the production of new viral particles, but there was no new production of bacterial cells in the Ptreatment. Hence, the virus-to-bacteria ratio was much higher in the P-treatment than in the N-treatment and the control.

The high relative abundance of NuCC (accounting for about $85 \%$ of all bacterial cells) in our experimental setup was an effect of the pre-incubations (2 to $6 \mathrm{~d}$ ), and was mainly due to a decrease in non-NuCC (Fig. 1). In a similar dilution experiment, Gasol et al. (1999) found that bacteria with high DNA contents increased from 40 to about $85 \%$ during $30 \mathrm{~h}$ under predator-reduced conditions (in $0.8 \mu \mathrm{m}$-filtered water). These authors also showed that bacteria with high DNA contents were well correlated both with the abundance of NuCC and the abundance of 'Live' cells (determined with a Molecular Probes Live/Dead BacLight bacterial viability kit). In freshwaters, a good correlation between the abundances of $\mathrm{NuCC}$ and bacteria with an active electron transport system, as indicated by the redox-sensitive dye CTC, has been demonstrated (Berman et al. 2001).

In conclusion, our results indicate that viruses can be responsible for the production of non-NuCC through infection and subsequent lysis of host cells. Increased availability of $\mathrm{P}$ can stimulate virus production without first stimulating production of new bacterial cells.

Acknowledgements. Financial support was provided by the Helge Ax:on Johnsson Foundation (to K.V.). The helpful comments of 3 anonymous reviewers are also acknowledged.

\section{LITERATURE CITED}

Bergh Ø, Børsheim KY, Bratbak M, Heldal M (1989) High abundance of viruses found in aquatic environments. Nature 340:467-468

Berman T, Kaplan B, Chava S, Viner Y, Sherr BF, Sherr EB (2001) Metabolically active bacteria in Lake Kinnaret. Aquat Microb Ecol 23:213-224

Blomqvist P, Bell RT, Olofsson H, Stensdotter U, Vrede K (1995) Plankton and water chemistry in Lake Njupfatet before and after liming. Can J Fish Aquat Sci 52:551-565

Bratbak G, Egge JK, Heldal M (1993) Viral mortality of the marine alga Emiliania huxleyi (Haptophyceae) and termination of algal blooms. Mar Ecol Prog Ser 93:39-48

Chaney AL, Marbach EP (1962) Modified reagents for the determination of urea and ammonia. Clin Chem 8: 130-132

Choi JW, Sherr EB, Sherr BF (1996) Relation between presence-absence of a visible nucleoid and metabolic activity in bacterioplankton cells. Limnol Oceanogr 41:1161-1168

DeBruyn JM, Leigh-Bell JA, McKay ML, Bourbonniere RA, Wilhelm SW (2004) Microbial distribution and the impact of phosphorus on bacterial activity in Lake Erie. J Gt Lakes Res 30:166-183

Fisher UR, Velimirov B (2002) High control of bacterial production by viruses in a eutrophic oxbow lake. Aquat Microb Ecol 27:1-12

Gasol JM, Zweifel UL, Peters F, Fuhrman JA, Hagström ^̊ (1999) Significance of size and nucleic acid content heterogenity as measured by flow cytometry in natural planktonic bacteria. Appl Environ Microbiol 65:4475-4483

Gobler CJ, Hutchins DA, Fisher NS, Cosper EM, Sanudo-Wilhelmy SA (1997) Release and bioavailability of C, N, P, Se, and Fe following viral lysis of a marine chrysophyte. Limnol Oceanogr 42:1492-1504

Haglund AL, Törnblom E, Boström B, Tranvik L (2002) Large differences in the fraction of active bacteria in plankton, sediments, and biofilms. Microb Ecol 43:232-241

Haglund AL, Lantz P, Törnblom E, Tranvik L (2003) Depth distribution of active bacteria and bacterial activity in lake sediment. FEMS Microbiol Ecol 46:31-38

Hessen DO, Andersen T, Lyche A (1990) Carbon metabolism in a humic lake: pool sizes and cycling through zooplankton. Limnol Oceanogr 35:84-99

Lindström ES (2000) Bacterioplankton community composition in five lakes differing in trophic status and humic content. Microb Ecol 40:104-113 
Maranger R, Bird DF (1995) Viral abundance in aquatic systems: a comparison between marine and fresh waters. Mar Ecol Prog Ser 121:217-226

Menzel DH, Corwin N (1965) The measurement of total phosphorus in seawater based on the liberation of organically bound fractions by persulphate oxidation. Limnol Oceanogr 10:280-282

Middelboe M, Lyck PG (2002) Regeneration of dissolved organic matter by viral lysis in marine microbial communities. Aquat Microb Ecol 27:187-194

Middelboe M, Jørgensen NOG, Kroer N (1996) Effects of viruses on nutrient turnover and growth efficiency of noninfected marine bacterioplankton. Appl Environ Microbiol 62:1991-1997

Middelboe M, Riemann L, Steward G, Hansen V, Nybroe O (2003) Virus-induced transfer of organic carbon between marine bacteria in a model community. Aquat Microb Ecol 33:1-10

Murphy J, Riley JP (1962) A modified single solution method for the determination of phosphate in natural waters. Anal Chim Acta 27:31-36

Noble RT, Fuhrman JA (1998) Use of SYBR Green I for rapid epifluorescence counts of marine viruses and bacteria. Aquat Microb Ecol 14:113-118

Noble RT, Fuhrman JA (1999) Breakdown and microbial uptake of marine viruses and other lysis products. Aquat Microb Ecol 20:1-11

Editorial responsibility: Jed Fuhrman,

Los Angeles, California, USA
Poorvin L, Rinta-Kanto JM, Hutchins DA, Wilhelm SW (2004) Viral release of iron and its bioavilability to marine plankton. Limnol Oceanogr 49:1734-1741

Proctor LM, Fuhrman JA (1990) Viral mortality of marine bacteria and cyanobacteria. Nature 343:60-62

Riemann L, Middelboe M (2002) A minireview-viral lysis of marine bacterioplankton: implications for organic matter cycling and bacterial clonal composition. Ophelia 56: $57-68$

Tuomi P, Fagerbakke KM, Bratbak G, Heldal M (1995) Nutritional enrichment of a microbial community: the effects on activity, elemental composition, community structure and virus production. FEMS Microbiol Ecol 16:123-134

Vrede K, Vrede T, Isaksson A, Karlsson A (1999) Effects of nutrients $(\mathrm{P}, \mathrm{N}, \mathrm{C})$ and zooplankton on bacterioplankton and phytoplankton - a seasonal study. Limnol Oceanogr 44:1616-1624

Williamson SJ, Paul JH (2004) Nutrient stimulation of lytic phage production in bacterial populations of the Gulf of Mexico. Aquat Microb Ecol 36:9-17

Wolf A, Zheng T, Witzel KP, Jost G (2004) Impact of initial phage/host ratio and nutrient addition on coexistence in a phage-host system. Aquat Microb Ecol 35:131-139

Zweifel UL, Hagström Å (1995) Total counts of marine bacteria include a large fraction of non-nucleoid containing bacteria (ghosts). Appl Environ Microbiol 61:2180-2185

Submitted: June 7, 2005; Accepted: April 5, 2006

Proofs received from author(s): June 9, 2006 